\title{
Terror and Weapons of Mass Destruction in the Light of Risale-i Nur
}

\author{
Prof. Dr. Yunus ÇENGEL \\ Adnan Menderes Üniversitesi, Aydın \\ University of Nevada, Reno, USA
}

\begin{abstract}
While technological innovations that are progressing at a head-spinning pace have made life easier and raised the quality of life to levels unimaginable half a century ago, the same technological innovations, when fall into the wrong hands, can turn into dangerous devices that can destroy peace and order, and even threaten the very existence of humanity. The ease of destruction, and the potential of technological wonders being used as weapons of terror have caused people to be concerned and to have a gloomy outlook towards the future. Knowing that the existing amount of nuclear weapons have the power to destroy the entire world a hundred times over is causing us to question the future of humanity, and the ease of production and use of biological and chemical mass destruction weapons that can destroy animals and plants together with innocent people in an area have raised our level of concern. Transportation vehicles that are manufactured for peaceful purposes can turn an area into a war zone, and the military and security measures to prevent such use are proving to be inadequate.

No baby comes to this world as a terrorist, and no child dreams about becoming a terrorist when he or she grows up. Therefore, fighting terror is only possible by identifying and calming the feelings that move and feed the tendencies of destruction and hostility in people, who are at the highest level of creation. This can be made possible by true Islam that upholds justice, assistance, and love, and respects the rights of all creatures. The most effective war against terror can be fought by upholding 'righteousness' that establishes justice and peace, 'virtue' that results in brotherly love and harmony, and 'mutual assistance' that establishes unity and solidarity and eliminates fights. This can be made possible by equipping the current civilization that is based on force, benefit, and conflict with high moral values.

After the verses related to matters of belief, the most cited and emphasized verses in the Risale-i Nur are 'No bearer of burdens can bear the burdens of another (Qur'an, 6:164) and "One who kills a person who has not killed anyone or has not caused public unrest in the world is like one who has killed all people" (Qur'an, 5:32). In the light of the explainations of these two verses and the emphasis placed on positive action in Risale-i Nur, it is not possible to justify terror and the use of weapons of mass destruction which causes countlsess innocents to die. Over a century ago Bediuzzaman declared that the time for struggle with the sword is over and that in this modern age any struggle will be by the pen.
\end{abstract}

Keywords: Terror, weapons of mass destruction, positive action, Risale-i Nur, Nursi 


\section{Introduction}

Recent developments in communication technologies have put the globe in the living room of each house, and an event in a distant corner of the world can affect the lives of everyone everywhere. We are saddened by the sorrow of the people we see on the TV screen, and rejoice with their happiness. An event of general interest, such as the Olympics, can turn all people into a family and the whole world into a living room. The use of Internet in recent years at an increasing rate has amplified the flow of information and accelerated globalization. Now, everybody is becoming a 'world citizen' in a real sense, and a problem in some part of the world can become the problem of all people.

The capability of TV screens and computer monitors to mirror an event like it is happening at millions of places at once wets the appetite of evil-minded people as well. An event that attracts the attention of printed and visual media is multiplied by these screens, and ends up having the impact of a million events. This magnified effect destroys the peace of mind of many, shatters hopes, and stabs spirits. An impact of this magnitude serves as base for new ill-intentioned acts. For this reason, the news media organizations have great duties and responsibilities in the fight against terror. A news organization that projects a terrorist act in graphic detail into all parts of the world and injects all destructive ingredients into millions of unsuspecting minds in the name of "fast and true newsman ship' is in fact the biggest partner of terrorists, and lays the ground for new such acts. The principles "Everything you say must be right, but telling all the right things is not right" and "Description of falsehood in great detail is a mislead for simple minds." "should be guides for news reporters.

Turning on the TV and watching the frightful events in the world with curiosity poses a serious threat to psychological and mental health, and leaves sensitive people in sorrow. Bediüzzaman cautions against knowingly harming oneself this way:

"Now everyone in the planet is disturbed either physically, or mentally, or psychologically, or emotionally from dreadful events, and is in pain and misery. In particular, the misguided and heedless suffer from the excruciating and horrendous pain of humanity because of their concern for others in addition to their own pain, since they are unaware of the general heavenly grace and encompassing and mysterious heavenly wisdom. Because they needlessly neglect their main duties and important obligations, and turn their attention with curiosity to external political fights and universal events and get mentally involved, their souls are shaken and their mind confused. ... I am of the opinion that in these storms and fires of the globe, the ones that preserve the peace of the mind and the tranquility of the heart are those who truly believe and completely trust in God and be totally pleased with Him." 3 
The real reason behind the concern for the clash of civilizations is not the conflicts or oppositions among civilizations, rather, it is the fear and distrust among the members of different civilizations. That is, it is the conceived phobia that stems from not knowing each other. Establishing an atmosphere of trust by forming closer and warmer relationships will dissipate these fears and will help establish global peace. Bediüzzaman explains the aggression of some minorities in the early part of the $20^{\text {th }}$ century in a similar manner:

"I think their aggression is in retaliation to the presumed aggression from you and a show of force against the conceived aggression from you. If they are totally convinced that there will be no aggression from you, they will be content with justice." 4

Presumed fears can be cause for war even today, and mutual trust can be established by eliminating such fears. The historical fact that members of different religions have lived in Jerusalem and Palestine side by side for hundreds of years in peace and mutual trust during Ottoman times shows that global peace is possible so long as justice and basic human rights are observed and equality before law is upheld. If those people who come from a tradition of peace and respect are resorting to terror today, the causes behind it should be investigated. When those causes are eliminated, peace and tranquility will certainly return to that heartland.

One of the most basic and most important senses in people is the "sense of fear". This sense, which is given to preserve life, can ruin one's life instead and turn life into hell when abused. The ill-intentioned propagandists utilize this sense of fear a lot to shape public opinions. They can justify many atrocities and injustices by stirring this sense and blowing it out of proportion, and they can desensitize the public on matters that the public is normally sensitive about. The ill-intentioned people use the sense of fear as an effective weapon to engineer the reactions of a society.

Bediüzzaman stresses that living in constant fear destroys the quality of life, and advises that even in personal matters it is better to overlook past animosities and establish peace:

"It occurred to me to explain a truth to you which will save you both from worldly torment and the torment of the Hereafter. It is as follows: For example, a person killed someone's brother or one of his relatives. A murder that yields one minute's pleasure of revenge causes millions of minutes of both distress for the heart and the anguish of prison. And the fear of revenge by the murdered man's relatives, and anxiety of finding himself face to face with his enemy drives away all his pleasure and enjoyment in life. He suffers the torment of both fear and anger. There is only one solution for this, and that is reconciliation, which the Qur'an commands, and truth, reality, benefit, humanity, and Islam require and encourage. Indeed, the reality and requirement is peace." 5 
Bediüzzaman states that nurturing animosity in the heart is animosity towards self, and he advises that those who love themselves should not allow the feeling of hostility and vengeance enter their hearts. This advice is equally valid for states. Well-aware of this, France and Germany buried their past animosity in history shortly after the World War II and poured the foundation of lasting peace - a movement that formed the foundation of the European Union, which is a growing union of lasting peace.

The biggest obstacle in the path of advancement of mankind, and thus general peace and tranquility, is bigotry that narrows people's angle of view, and causes them to view everything with suspicion and enmity. The reason for bigotry is ignorance, and its remedy is enlightenment with knowledge. Bediüzzaman states that the obstacle of bigotry has largely been disappeared with the advance of civilization:

"A person who puts on black glasses sees everything black and ugly. As such, if the perceptive eye of the person is veiled by hypocrisy, and his heart is wrapped with non-belief, everything will seem ugly and bad, and this may cause enmity and resentment towards all people and even the universe." 6

In order to take the wind of time behind and fill the sails and catch the time, it is necessary to read the flow of time well and to act accordingly. Otherwise, in football terms, one may find himself in offsite, and all efforts can go to waste. As it is unthinkable today to treat illnesses using the medical sciences and medicines of the last century, so it is impossible to solve the current problems of society and the world using the methods of the past. Today's problems are very different in scope and size from those of yesterday, and their solutions require very different approaches. For example, the actions of individuals and societies in the past were ruled by emotions rather than the mind and knowledge, and as a result, bigotry and disunity were commonplace. Individuals and societies were lead by appealing to these emotions rather than convincing the mind with reasons. Nowadays the mind, sciences, justice, goodwill, and public interest rule instead of the emotions, and the states that have adhered to these present-day values are rightfully called contemporary states. The backwardness of the states that have stick to the past with bigotry and turned their back to contemporary values is worth thinking about. The states that have remained in the dark corners of the past should analyze this picture carefully.

The path of time and the route of the world show that humanity will adhere to contemporary values, and will unite around them. Bediüzzaman expresses this as:

"The school of emotions that is called the past, and the academy of thoughts that is called the future are not of the same form. ... The relatively simple manners and the pure emotions of the people of the past suppressed and ruled over 
their unenlightened minds, which resulted in the spread of individuality and division. But the relatively enlightened minds of the people of the future took control over their blind emotions tainted with lust and desire and forced them to abide by the mind, which is assurance that justice for all is to become common place. Humanity has prevailed to some degree. It gives glad tidings that Islam, which is the real humanity, will shed light over the gardens of Asia like clear sun in the cloudless skies of the future."7

The Islamic world should listen to this good news, and should strip itself from the baseless fears and hesitations and jump into the wagon of our time. Those already in that wagon are not strangers - they are fellow human beings. Those who look at wars, terrorist acts, hostilities, and tears in various parts of the world see no light of hope, and predict with pessimism that the differences will grow wider, and darker days are awaiting us in the future. Bediüzzaman, on the other hand, sees a totally different view when he looks at the future with the binoculars of faith and divine wisdom:

"As has been established by the prying investigations and innumerable experiments of the sciences, the fundamental and absolutely overriding aim and the true purpose of the All-Glorious Maker in the order of the universe are good, beauty, excellence and perfection. For all the physical sciences demonstrate such an order and perfection in the fields they study in accordance with their comprehensive laws that the intellect can find nothing more perfect." 8

In the future, with the complete development of sciences and humanity, the human race will surely comply with this perfection in the universe, and prove that humanity is the greatest fruit of the tree of creation. "As civilization, virtue, and freedom become more and more dominant in the world of humanity, the other side of the balance will necessarily get lighter and lighter. ${ }^{9}$

\section{Maintaining Peace and Practicing Justice}

Human beings are naturally inclined towards beauty, perfection, goodwill, and justice. They like these attributes, and dislike their opposites that are ugliness, imperfection, selfishness, and injustice. A civilization can be a real civilization and become a means of progress only if it possesses high attributes. A criterion for this is to attract rather than repel, and to result in virtuous acts that human consciences can easily accept. Otherwise, it is a deceptive civilization and even savagery, and it can lead humanity to disaster rather than happiness. A proof of this is that the technological advancements and the fast industrialization in the first half of the $20^{\text {th }}$ century have resulted in two world wars, the death of millions of people, and the near ruining of the world. A system that benefits a small minority while leaving the great majority in poverty and deprivation cannot be a civilization; it can only be a mechanism of cruelty.

The fruits of the current Western Civilization are not appealing at all. It appears 
that a small minority lives in wealth and luxury while most people live in poverty and even in hunger. This situation feeds the feelings of jealousy, hatred, animosity, and revenge, and if they are not controlled, these growing feelings can take over. A person under the control of these feelings can turn to acts such as theft, sabotage, murder, rebelling, and terror, and can ruin peace and tranquility in a society. Therefore, the current shortsighted Western Civilization that is based on 'self-interest' and 'self-gratification' is serving as a mechanism that destroys the peace in societies and even the world. So it must budget a large amount of resources to eliminate these threats by police and military force.

Terror can be considered in two parts, and both are associated with the feelings of caring and compassion. The feelings of caring and compassion in people are the source of the tendencies of protecting the loved ones, eliminating the threats and dangers, and even attacking those who show hostility. Even fearful creatures - such as hens - are often observed to turn to brave warriors when the feeling of compassion is stirred. If a strong belief and its outcomes that are trust in God and submission to Him do not completely rule in the heart, a person can loose control of himself as the feelings of compassion and care burst out under strong emotional distress such the harassment or murder of the loved ones, and the awakened feelings of revenge and destruction can control this normally peaceful person. The mind and the conscience can no longer keep the person from such acts, and the person becomes "temporarily insane." People whose intellectual faculties are disabled under such heavy emotional stress may not even be responsible for their acts, and in the American legal system, suffering from temporary insanity is a valid basis for the claim of innocence. Those who go after terror by using cruelty and force to deter others by instilling fear often spread the terror and cruelty by turning emotional people whose senses of compassion are injured into wounded lions - just like turning harmless bees into killer bees by inserting a stick into bee hives. Such people may regret what they have done when things calm down and they come to their senses, but it may be too late.

The reasons behind the more violent second kind of terror and anarchy are the corruption of the heart, the diminishing of the feelings of compassion and care due to the destruction of moral values, and the turning of people into wild beasts who are not disturbed by inflicting pain to others (even liking it), like snakes. Such people have surfaced in recent years in growing numbers, and they are the real threat to the future of the civilization and humanity:

"Socialism sprang up in the French Revolution from the seed of libertarianism. Then since socialism destroyed certain sacred matters, the ideas it inculcated turned into bolshevism. And because bolshevism corrupted even more sacred moral and human values, and those of the human heart, of course the seeds it 
sowed will produce anarchy, which recognizes no restrictions whatsoever and has respect for nothing. For if respect and compassion quit the human heart, those with such hearts become exceedingly cruel beasts and can no longer be governed through politics."10

\section{Fighting Terror}

The biggest mistake in the fight against terror is to think that terror can be prevented by military and security measures since the terrorists are few by number and weak by resources. Superiority is not a valid criterion in the fight against terror because terror is destruction, and destruction is easy. Major damage can be done with little force. Sometimes a single person with a single match can burn a large area with many houses in it, and hundreds of firemen with their modern equipment may feel powerless in fighting the fire. In the words of Bediüzzaman:

"For the most part, misguidance and evil are negative, destructive, and pertain to non-existence. While in the great majority of cases, guidance and good are positive, constructive, repairing, and pertain to existence. Everyone knows that one man can destroy in one day a building made by twenty men in twenty days. Yes, although human life continues through the existence of all the basic members and conditions of life, and is particular to the All-Glorious Creator's power, through severing a member, a tyrant may make the person manifest death, which is non-being in relation to life. The saying 'Destruction is easy' has for this reason become proverbial." 11

Any results obtained by offering rewards or instilling fear are temporary and superficial. Effective and lasting fight against terror is only possible by eliminating the causes that awaken, feed, and stir the senses of destruction and hostility in people. So long as these tendencies are alive and well, all efforts in fighting terror is bound to go to waste. This can be achieved by subscribing to truth and fairness that rule over minds, warm the hearts, establish control over human conscience. Bediüzzaman expresses this elegantly as follows:

"With the deception of motivation and intimidation one can only have a superficial effect and keep the mind in line. Impinging into the depths of the heart, moving even the most delicate senses, flourishing the inner talents like a blossoming rose, shaking and mobilizing the hidden and dormant talents and tendencies, causing the essence of humanity to gush out, and exhibiting the value of articulation are from the glimpses of the rays of truth. Yes, polishing of the hearts from revolting practices such as burying of the girls while alive, which is a monument of stone heartedness, and gilding the hearts with virtues like mercy to animals, even compassion to ants, which is a flash of delicacy and tenderness, are such great revolutions - especially in such ignorant and stubborn tribes - that, because no natural laws are utilized, all observant and truthful people will admit that this is extraordinary." 12

The most effective and civilized way of fighting flies is via cleanliness. Because flies multiply at dirty places, and smelly dirt attracts them. Fighting flies with 
chemicals is both expensive and short-lived, and it poses risks to those exposed to the chemicals. Besides, the garbage damps will continue to serve as production sites of flies so long as they exist, and the only winners from this fight will be the chemical companies. Also, mosquitoes can be fought most effectively by getting rid of swamps or by treating them properly when the mosquitoes are still larva. Likewise, the most effective treatment against pests like anarchy, murder, transgression, and terror that threaten today's civilization is to dry up the swamps of selfishness, exploitation, and injustice that produce and feed them by the medicines of compassion, assistance, and justice. That is, to treat today's civilization with heavenly principles that prescribe compassion and justice as basis in all affairs. Otherwise, resorting to force instead of compassion and strength instead of justice cannot get rid of these pests; to the contrary, the use of force causes those pests to spread and multiply faster, exposing the world to a greater danger.

We call up on those whose hearts are hard towards the needy but budget billions of dollars to fight terror: You can solve this problem permanently and at much lower cost and by changing hostilities to friendships. The way to such a solution passes from being civilized not only in the body but also in the soul; that is, from virtue. Otherwise, all of your money and the effort will go to waste. Terror will be increasing rather than decreasing, and you will lose more sleep over it.

\section{Reason and Public Opinion}

As Bediüzzaman often expresses, different things are fashionable in different times, and different trends rule. Those who are not aware of the valuable commodities of their time and do not see the way the time is flowing are like those who row against the current, and their entire effort is bound to go to waste. In old times, the engine of the time machine was force. But in these modern times, it is the mind, compassion, and conscience, and those who fail to see this will fall down no matter how strong they are. Their hammer will strike on their heads first. In the words of Bediüzzaman:

"The ruler of the old times was strength; the one with the sharp sword and a stony heart would rise. But the motor, the soul, the strength, the ruler, and the boss of the times of freedom are righteousness, mind, knowledge, law, and public opinion. Only those with a sharp mind and a bright heart will rise to the top. Since knowledge increases with aging and strength decreases with growing old, the Middle-age states that are based on strength are destined to collapse while the contemporary states being founded on knowledge will have a Hizır-like (eternal) life." "Your bosses, chiefs, and even spiritual leaders, if founded on strength and maintain sharp swords, will necessarily fall, and this is what they deserve. Those who stand on reason, utilize love instead of force, and keep their mind over their emotions, will not fall; they may even rise further."13

Bediüzzaman explains how the developed countries can be caught and even 
passed: "You can beat them with the same weapons that they beat you: the mind, the idea of nationalism, fondness of progress, and sense of justice." 14

Bediüzzaman warns those who fail to see the necessities of the time and the direction of the world, and insist on using brutal force rather than the mind, love, and conscience: "As for the one who strikes with the sword, the sword turns back and hits his own innocent. Now victory is not with the sword. There is a place for the sword, but it is the hand of the mind." 15

The events in recent years seem to confirm this assessment. Those who resorted to brutal force and even suicide bombers - even for a right cause - are labeled as terrorists, and brought misery and tear shed to their people rather than victory and happiness. Likewise, even the superpowers who thought they are so powerful that they can do anything but are unaware of the reality of time have hit the invisible wall of time, and shot themselves with their own weapons.

Judging from the realities of time that Bediüzzaman brought to our attention we can say that: Those who invest in arms and brutal force as they have been doing in the past are investing into nothing. Those who invest in the mind, sciences, research, love, justice, and public opinion will see their investment multiply, and achieve all of their goals easily - even if they are weak in armed forces. Those who think they can achieve their just cause by resorting to brutal force and terror sparked off by the feelings of revenge and hostility should put aside these negative feelings and reevaluate their approach with a clear mind - if, of course, they want to put an end to their humiliation and suffering. Also, those who spend their time and resources to develop or acquire nuclear or other weapons of mass destruction should wake up quickly from these dreams whose time has passed. Otherwise these weapons will strike the invisible wall of time, and explode on their own heads.

Technical work conducted with no regard of basic principles of sciences is sure result in failure. Likewise, any action incompatible with social principles, the realities of the situation, and the realities of time is bound to backfire and end up in failure. Those who ask for the help of God should first obey to the laws and principles God has dictated in this universe. Otherwise, he will be viewed as a rebel, and his request will be rejected. As Bediüzzaman puts it:

"Whoever wants Divine help, should familiarize himself or herself with Divine laws, creation, and nature, and work in accordance. Otherwise, the nature will give an answer of 'no' by denying the request. The general flow of things, on the other hand, will throw those who go in the opposite direction to a hole of nonexistence." 16

\section{Weapons of Mass Destruction}

In a world which is getting smaller and smaller and is interwoven with a 
network of communication, it has become extremely difficult to go against the general opinion of the public, and the common conscience of the public has become the biggest obstacle in the use of the weapons of mass destruction. A proof of this is the fact that although many wars have been fought since the world war II, no country has dared to use nuclear weapons, including the United States that has lost over 58,000 soldiers in Vietnam war in a humiliating defeat. The only thing that can possibly justify the use of nuclear weapons is the fear of being attacked by such weapons, and it can be said that the best assurance against being attached by nuclear or other weapons of mass destruction is to close the door firmly to these kinds of weapons.

Bediüzzaman, labels the verse "No bearer of burdens can bear the burdens of another (Qur'an, 6:164) as "the most just Qur'anic principle", and the verse "One who kills a person who has not killed anyone or has not caused public unrest in the world is like one who has killed all people" (Qur'an, 5:32) as "a person's life or blood cannot be sacrificed even for the entire humanity. Both are equivalent from the point of view of power, as they are equivalent from the point of view of justice." 17

In the light of these explanations, it is unthinkable for a Muslim to use a weapon of mass destruction that may cause the annihilation of countless innocent men, women, children, animals, and trees. The highest level religious councils in many countries, including Iran and Egypt, expressed similar opinions. The claim to possess these weapons for the purpose of deterring enemies rather than using them does not sound convincing.

The destruction of all weapons of mass destruction - including nuclear weapons - in the possession of Islamic states, ending of any research and development programs on such weapons, and the declaration to the whole world that, even when they are bombarded with such weapons, they will never respond in kind because they view the use of such weapons as a inhumane behavior and savagery will have the effect of an atomic bomb in the shattering of the thick walls of fear and prejudice built around Islam and Muslims and the exposure of the core of Islam filled with love and compassion. It should not be forgotten that even today the expressed reason for many wars is "preemptive strike against a probable attack". The elimination of baseless fears and suspicions will eliminate the justifications for such wars, and the world will become a safer place.

Bediüzzaman asserts that the claim that the tension and distrust between the Western World and the Islamic World is leading towards the clash of civilizations stems from baseless fears and misconceptions, and states that these clouds of baseless fears that block the rays of the Islam will be wiped out by education that equips people with the desire to seek the truth, the love of humanity, and the 


\section{human conscience:}

"The biggest barrier between us and the Westerners is the baseless fears of clashing and refutation stemming from deceptive imagination related the extremities of Islam and scientific matters. Bravo to the enlightening support of schools and the factual support of sciences for equipping the truth with the tendency to investigate, the love of humanity, and the human conscience and for shattering those barriers then and now. Yes, the biggest causes that deprived us from the comfort of this world and the Westerners from the happiness in the hereafter and curtailed the sun of Islam are the misunderstandings and the baseless fears of clashing and opposition."18

Bediüzzaman often states that Risale-i Nur collection, which unifies physical and social sciences with religious teaching, serves as a guardian of peace, and the moral damage in the minds and hearts of people can be only by moral atomic bombs:

"Now in all mankind treaties are signed and measures are taken to protect humanity from corruption and to preserve general peace. ... Risale-i Nur's preserving of peace in this land and nation - although there are more causes to disturb peace and safety here compared to other nations - shows that the establishment of Eastern University will help humanity to enjoy general peace. This is because the damage nowadays is moral, and thus there ought to be a curative moral atomic bomb to repair it. A definite proof for the damage in this time and age being moral and this damage can possibly be counteracted only by curative moral atomic bombs is the Risale-i Nur's standing as a barricade against the attacks of misguidance, materialistic philosophy, and atheism within this thirty years. Risale-i Nur has become a restorer and moral atomic bomb against this morality damage." 19

\section{Terror and Islam}

Like every bright object reflecting the sunlight, and every transparent object containing a little sun in it, the good or bad acts of individuals reflect on the members of the community they belong to, and one act becomes a thousand and even a million acts, depending on the size of the community. As Bediüzzaman puts it:

"Through the bond of this sacred nationhood, all the people of Islam become like a single tribe. Like the members of a tribe, the peoples and groups of Islam are bound and connected to one another through Islamic brotherhood. ... If a member of one tribe commits a crime, all the members of the tribe are guilty in the eyes of another, enemy tribe. It is as though each member of the tribe had committed the crime so that the enemy tribe becomes the enemy of all of them. That single crime becomes like thousands of crimes. And if a member of the tribe performs a good act that is the cause of pride affecting the heart of the tribe, all its members take pride in it. It is as if each person in the tribe feels proud at having done that good deed. It is because of this fact that at this time, and particularly in forty to fifty years' time, evil and bad deeds will not remain with the perpetrator; they will transgress the rights of millions of Muslims. Numerous examples of this shall be seen in forty to fifty years' time."20 "Now a sin does 
not remain as 'one', it becomes 'one thousand'."21

The silence of the Islamic world towards terror stemming from Muslims and its lack of reaction is astonishing. It looks as if siding with fellow Muslims in disputes with others is a necessary part of religious brotherhood. But Islam is truthfulness, and a Muslim can support only truthful acts.

"Truthfulness is the basis and foundation of Islam, and the bond between people of good character, and the basis of elevated emotions. Since this is so, as the foundation of the life of our society, we must bring to life truthfulness and honesty, and cure our moral and spiritual sicknesses with them. Yes, truthfulness and honesty are the vital principles in the life of Islamic society."22

Islam and terror are the opposites of one another, just like day and night, and a terrorist destroys Islam first. Supporting all acts of a Muslim is not religious zeal; it is simply blind partisanship. Supporting an unjust act in the name of Islam is injustice to Islam first. It causes Islam to be equated to injustice, and it builds a dark wall and blocks the beauty of Islam. In the words of Bediüzzaman

"A person is not liked for who he is; but more likely for his attributes and workmanship. Therefore, every attribute of every Muslim does not necessarily have to be Muslim, and all attributes and works of every nonbeliever do not necessarily have to be nonbelievers." 23

In fact, true love and loyalty to Islam requires to fight against those who misrepresent Islam. The past verdicts about the roundness of the earth can shed light on this matter:

"[Imam Gazali] has passed this verdict: 'Whoever denies and refuses to believe an act such as the roundness of the earth whose validity is based on definite evidence on the grounds of religious zeal, commits a major crime against the religion. Because this is treason, not loyalty. .... [Huseyin Cisri] threatens the nonbeliever of the roundness of the earth with a loud voice, and declares with the strength of the truth with no hesitation that 'whoever denies the roundness of the earth on the basis of religion with religious zeal is a fool friend, who causes greater harm than a severe enemy." 24

As stated above clearly, those who do wrong in the name of religion - no matter how loyal and good willed they are - cause more harm to the religion than the fiercest enemy of the religion:

"An ignorant friend can cause as much harm as an enemy. Until now, I used to watch the enemy only and break their transgression with the diamond sword at hand. But now I am obliged: To bring those friends in line, I will use that sword to poke into their uneducated and excessive dreams." 25

For this reason, fighting those who do wrong in the name of religion is like fighting the enemies of religion. From the destruction-natured souls armed with hostility we can expect only destruction and hostility - even if they are watered 
with Islam. "The bee drinks water and makes honey, the snake drinks water and makes poison." 26

Likewise, the delicate sunlight that enlightens the world can cause the things with a tendency to go bad to decompose and stink.

For Muslims to support and to side with each other in wrongdoing is not necessarily due to Islamic brotherhood; rather, it may be due to political partisanship. Bediüzzaman expressed the criterion for it as follows:

"Whoever prefers his impious political partner to his pious opponent ill-intentioned excuses, he is motivated by politics. One who claims with possessiveness that his party is better suited to represent the religion, the sacred item that belongs to all, and in so doing stirs emotions against the religion and damages the image of religion in minds of great majority, is motivated by partisanship."27

Bediüzzaman often states that the time for armed struggle has passed, and that the struggle from now on will be by good acts and progress in all areas:

"In the past, Islam's progress occurred through smashing the enemy's bigotry and obstinacy and through defense against their aggression; through weapons and the sword. Whereas in the future, in place of weapons, the immaterial, moral swords of true civilization, material progress, and truth and justice will defeat and scatter the enemies." 28

The humanity is transposing from the age of savagery and ignorance to the age of civilization and knowledge. In a world that has completed the phase of civilization, any wars can only be with words rather than arms. Those who conquer the minds with reason and elegance will conquer the world.

"The way of this Union is love; its enmity is only for ignorance, poverty, and strife. Non-Muslims should feel sure that this Union attacks only those three facts. Our actions towards non-Muslims consist only of persuasion, for we know them to be civilized. And we suppose them to be fair-minded, so we should demonstrate that Islam is lovable and elevated." 29

Bediüzzaman expresses that the time for hostilities has passed, and now is time for love:

"The time for enmity and hostility has finished. Two world wars have shown how evil, destructive, and what an awesome wrong is enmity." "What I am certain of from my experience of social life and have learnt from my life-time of study is the following: The thing most worthy of love is love, and that most deserving of enmity is enmity. That is, love and loving, which render man's social life secure and lead to happiness are most worthy of love and being loved. Enmity and hostility are ugly and damaging, have overturned man's social life, and more than anything deserve loathing and enmity and to be shunned." ${ }^{30}$

Terror associated with Islam has been in the world agenda for years, but the Islamic world's sidestepping the issue and failure to take a clear position on terror 
has strengthened preconceptions that tie Islam with terror. The weakness of individual reactions to terror and their inconsistency has neither had any significant effect on Muslims nor has it been sufficient to correct the tainted image of Islam. This bothers the sincere Muslims who feel every stabbing to Islam in their chests, and leads them into hopelessness and dismay. The main reason behind this insensitivity, despair, and the anarchy of ideas is the absence of an authority, and this deficiency should be remedied right away. This vacant position should be filled not by one person, as in the past, but by a committee that is composed of 20-30 most distinguished scholars of the Islamic world. The Muslims of the world will trust such an authority that forms a representative body, will follow its authoritative rulings, and will ignore the weak individual voices opposing the verdicts of such authority. This mechanism will also expose the evildoers who currently find the area wide open to spoil the unsuspecting innocent minds, and ensure that those evildoers are not welcome. "A single piece of truth is superior to a lot of dreams." 31 This way, the unfounded fears that leave Islam and the Muslims under suspicion will disappear, despair will be replaced by hope, and the assessment "The key and discloser of the continent of Asia and its future is mutual consultation" 32 will be realized.

Bediüzzaman expresses the need for a high consulting committee as follows:

"This committee should be formed such that the Islamic world can trust this position. It should serve both as a source and as a position of reflection of ideas. It should be able to carry out its religious duties towards the Islamic world completely. We no longer live in old times. In the past, the governing authority was a single person. The advisor of that person on religious affairs could also be a single individual. He could verify or modify the ruler's ideas. But the time now is the time for collaboration and community. The governing body is a collective personality extracted out of the spirit of the community who is rather insensitive, kind of deaf, and strong, and the consulting bodies represent that spirit. A governing body of this sort should have an in-kind religious advisor, which should be a collective personality that borne out of a consulting body of prominent scholars. This way, it can make its voice heard, and can lead people to the right path from points related to religion. Otherwise, even if the individual is a genius, a single person will sound like a mosquito compared to the collective personality of the community." 33

\section{Terror and True Faith}

Tue faith that is a source of love, and terror that is an outbreak of hatred and hostility cannot be associated. It is unfortunate that the dominance of the feeling of hostility on a person to the point of ultimate sacrifice of one's life is confused with the apex of belief that prohibits people from knowingly stepping on ants. The deepest sleep is thought to be awakening, and in the words of Bediüzzaman:

"In my youth I used to think that I reached the highest point of awakening. Now 
I understand that that awakening was not really awakening; it was the state of being in the deepest well of sleep. Their example is like a sleeping person who supposedly wakes up in his dream and tells his dream to others. Where in fact, the waking up in the dream is indication that he has left the light level of the sleep and entered into the deep and heavy level. Such a sleeper is like a dead."34

Those who resort to terror in the name of Islam should be shaken forcefully and be awakened from this deep confusion.

A fundamental principle of Islam is to love for God, to dislike for God, and to judge for God. Otherwise, people act by the desires of their soul, and commit injustice instead of justice. Islam, which should be a darling to the hearts, is equated with fear and terror as a result. Bediüzzaman narrates the following related story:

"Imam Ali (May God be pleased with him) once threw an unbeliever to the ground. As he drew his sword to kill him, the unbeliever spat in his face. He released him without killing him. The unbeliever said: 'Why did you not kill me'?' He replied: 'I was going to kill you for the sake of God. But when you spat at me, I became angered, and the purity of my intention was clouded by the inclinations of my soul. It is for this reason that I did not kill you.' The unbeliever replied: 'If your religion is so pure and disinterested, it must be the truth." "35

Bediüzzaman strongly warns those who mix religion with politics:

"A person controlled by not the holly principles of 'to love for God, to dislike for God' but, God forbid, by the devilish principles of 'to love for politics, to dislike for politics', showing hostility towards an angel-like true brother and love towards an evil political friend and approving his cruelties, may morally become a partner in those cruelties as well." 36

Signs that it is the belief that rules in the heart rather than the soul and desires are: to turn his face to the hereafter rather than the world, to be concerned with the sides of events facing the hereafter rather than the world, and to value the world only because it is the preparation ground of the hereafter. During the World War II when even some religious persons and scholars were leaving the congregation in the mosques and racing to listen to the radio, Bediüzzaman was asked why he did not show any interest in the war which has plunged the world into chaos and is closely connected with the fate of the Islamic world, and that if there is some event more momentous than the war. He responded by saying:

"Yes, an event more momentous than this World War and a case more important than that of world supremacy ... is that for everyone the case has opened by which they may either win, in return for belief, or lose, eternal properties as broad as the earth set with palaces and gardens. If they do not secure the document of belief, they will lose. And this age, many are losing the case because of the plague of materialism." 37

Also, even during the battle of Bedir, which is the most critical battle in Isla- 
mic history, the soldiers performed their prayers in congregation by the order of the Prophet, and earning the reward of congregation is preferred over the greatest event in the world. ${ }^{38}$ This being the case, can a true believer with a sound mind disregard the severe threat of the Qur'an "One who kills a person who has not killed anyone or has not caused public unrest in the world is like one who has killed all people" (Qur'an, 5:32) and risk his eternal life by resorting to terrorist acts? If he does, this shows a major weakness in belief, and this person must cure this most dangerous illness in his heart first.

Individuals can determine their level of belief by weighing the feelings of brotherhood and hostility in their hearts:

"Belief establishes real brotherhood, connection, unification, and solidarity among all things. But non-belief, like chill, exhibits all things as unrelated to one another, and portrays them as strangers to one another. For this reason, there is no enmity, hostility, and violence in the spirit of a believer. He has some level of brotherhood even with his greatest enemy." 39

Those who based their movement on Risale-i Nur whose core is compassion and the fortification of belief, have always been the preserver of peace and have remained distant to all forms of terror and anarchy:

"Compassion, truth and right, and conscience, the fundamental way of the Risale-i Nur, severely prohibit us from politics and from interfering in government. For dependent on one or two irreligious people fallen into absolute unbelief and deserving of slaps and calamities are seven or eight innocents - children, the sick and the elderly. If slaps and calamities are visited on the one or two, those unfortunates suffer also. ... Five principles are necessary, essential, at this strange time in order to save the social life of this country and nation from anarchy: respect, compassion, refraining from what is prohibited (haram), security, the giving up of lawlessness and being obedient to authority. The evidence that when the Risale-i Nur looks to the life of society it establishes and strengthens these five principles in a powerful and sacred fashion and preserves the foundation-stone of public order, is that over the last twenty years the Risale-i Nur has made one hundred thousand people into harmless, beneficial members of this nation and country." 40

A strong belief is a barrier against all injustice, including terror. When a believer is overcome by the feeling of revenge and is inclined to annihilate innocent lives, the verdict revealed from the Divine Throne comes to his mind. Through the sense of belief and ear of the heart, he as though hears the verses "No bearer of burdens can bear the burdens of another" (Qur'an, 6:164) and "One who kills a person who has not killed anyone or has not caused public unrest in the world is like one who has killed all people" (Qur'an, 5:32).

These divine commands activate the belief, which stir the intellect, heart, conscience, spirit, and other elevated inner emotions into action. The mobilization of 
these faculties gives rise to strong waves, and the intellect, heart, spirit, conscience, and the inner faculties attack the extinction tendency that comes from the soul and lust, and silence it. At the end, that tendency subsides, and the person decides not to commit the evil deed. Otherwise, the idea of getting caught and the fear of being imprisoned alone may not the strong enough to subside that evil tendency. As Bediüzzaman puts it,

"Belief places in the heart and mind a permanent 'prohibitor.' When sinful desires emerge from the soul, it repulses them, declaring: 'it is forbidden!' Man's actions result from the inclinations of his heart and emotions. They come from the sensibilities of the spirit and its needs. The spirit is stirred into action through the light of belief. If an act is good, he does it; if it is evil, he tries to restrain himself. Blind emotions will o longer drive him down the wrong road and defeat him." 41

\section{Punishing the Innocent together with the Criminals}

Unlike animals, no limit is put on the ability of people by their nature to do good or evil. The unbounded tendencies and feelings such as rebelling, injustice, and fearlessness, if left uncontrolled, can lead into great destruction. "With selfishness, one can turn into such a person that he wishes to destroy everything that stands on the path of his desires and yearning, even the whole world if he has the capability. ${ }^{42}$ The biggest injustice people commit is to punish many innocent people because of one's fault. Islam refuses this injustice with the most just principle "No bearer of burdens can bear the burdens of another" (Qur'an, 6:164).

Bediüzzaman explains the verse "Indeed, mankind is very unjust, very ignorant' (Qur'an, 33:72) as follows:

"Here is the terrifying ability of injustice in the nature of man. It means this: Unlike animals, the senses and tendencies of people are not limited. The tendency to commit injustice and the love for self can go very far. Yes, if self-concern, self-adoration, conceitedness, and pride and stubbornness, which are the ugly sides of selfishness and ego, join that tendency, the person can invent such greatest major sins that, the humanity could not find a name for it as yet. As it is evidence for the necessity of the hell, its punishment can only be the hell." 43

"As an individual, a person possesses many attributes. If one attribute among them attracts a hostile behavior, the Divine law in Qur'an 6:164 necessitates that hostility be limited to that attribute only, and feel pity for the person who is a collection of innocent attributes and refrain from any transgression against the person. But that cruel and ignorant person, with his cruel nature, assails the rights of all innocent attributes because of a single at faulty attribute, and even becomes hostile to the person, Still discontented, he extends his hostility to his relatives, and even to his colleagues." 44

Today such atrocities are committed in the name of fighting terror that the human conscience bursts out and rebels, and the feelings of destruction and hostility 
of victimized people are sharpened. As Bediüzzaman puts it,

"This civilization gives way to most horrible cruelties like if there is a traitor in a village, destroying that village together with its innocent; or if there is a rebel in a community, to annihilate that community together with all including children, or if a person who refuses to obey the unjust laws takes refuge in a sacred building like Ayasophia which is worth billions, to destroy that building. If, from fairness point of view, a man cannot be held responsible before God for the sins committed by his brother, how can it be that, thousands of uninvolved innocents of a town or community, in a place that is never free of bad-natured rebels or the uprising of a stubborn person, can be held responsible and even be annihilated." $" 45$

\section{Judging on the basis of Outcome}

The primary reasons behind divisions and clashing of ideas in the Islamic World are the examination and evaluation of issues from a narrow perspective, the disregard of the effects of changing times and conditions, and the inadequate involvement of the mind and reason. But:

"Every time or age has its own verdicts. The time we are in decrees the prohibition and abolition of some aged traditions. Having more evil than good calls for a verdict of death for such traditions. ${ }^{, 46}$

Even the Qur'an encourages people to think and to use their minds. Bediüzzaman attracts attention to the probable results when evaluating events and ideas:

"Look at the evidence and the consequences.... What distinguish alike trees are their fruits. Therefore, look at the consequences of my ideas and their ideas. In one it is rest and compliance. Hidden in the other are unrest and loss." "47 "The thing that shows the essence of something is its fruit." 48 Bediüzzaman warns those who fail to see the changing conditions of the world and dream about living in the past: "I will tell you something very short. You can memorize it. Here it is: The old way is no way; either new way or way to grave." 49

Those who resort to terror in the name of Islam and view this as a virtue should examine the consequences of these acts very carefully, and think about who benefit from such acts and the kinds of cruelty such acts lay the ground for, and answer these questions: After these terrorist acts, is it the friendship of people to Islam that has increased or is it the hostility? Has the name of Islam been elevated or tainted? Has the image and standing of Muslims in the world improved, or are the Muslims now being perceived as horrifying savages whose hearts are filled with hatred and hostility and who get pleasure out of blood shedding and murder? Have hearts of people feel warmer towards Islam or colder? Have the injustice and cruelty that initiated the terror ended or decreased, or have they returned more heavily and caused more pain and suffering for many more innocent people?

It appears that the only thing terror has accomplished is to lay the groundwork 
and to serve as justification for all these negatives and cruelties. It is hard to see the kind of logic and reasoning behind the insistence on wrong doing and failing to recognize the magnitude of damage caused. Bediüzzaman points out that "The origin of Islam is knowledge, and its foundation is the mind," and states that "accepting the truth and rejecting the unfounded falsehood" is the reputation of Islam. ${ }^{50} \mathrm{He}$ also brings to our attention that "Islam calls on and encourages reason and knowledge and protects scholars" as witnessed with verses from Qur'an such as "So will they not think, (36:68)", "So will they not reason, (6:50)" and "So will they not ponder on it, $(4: 82)^{51}$ What needs to be done is to evaluate the events and the words in the light of the mind, knowledge, and conscience before accepting or rejecting them.

\section{Mutual Assistance as basis for Global Peace}

Bediüzzaman sees mutual assistance as the key for peace and tranquility for people and classes of people in this globalized world. The establishment of lasting peace and general tranquility can occur only if the channels of assistance to the less fortunate are kept wide open:

"The bridge that maintains peace and order in social life is Zakat [alms giving]. In humanity, the life of social life is born out of mutual assistance. The cure and remedy for the calamities that stem from uprisings, revolts, and conflicts that prevent the advancement of mankind is mutual assistance." 52

"Zakat [alms giving] is a most essential pillar for happiness - not merely for individuals and particular societies, but for all of humanity. There are two classes of men: the upper classes and the common people. It is only zakat that will induce compassion and generosity in the upper classes toward the common people, and respect and obedience in the common people toward the upper classes. In the absence of zakat, the upper classes will descend on the common people with cruelty and oppression, and the common people will rise up against the upper classes in rancor and rebellion. There will be a constant struggle, a persistent opposition between the two classes of men. It will finally result in the confrontation of capital and labor, as happened in Russia." ${ }^{53}$

Eliminating the concern for injustices is only possible by establishing that strength is in righteousness - not the reverse. This can be done by enforcing fair rules that conform to general wisdom and the human conscience. Using such rules as the base in human affairs provides general peace and order in a society, and satisfies the sense of justice. This, in turn, increases the enthusiasm and passion, which is the key for advancement, and eliminates hopelessness, which is the biggest obstacle to advancement. The real civilization that will bring happiness, wealth, and dignity to the whole humanity and make the world a wonderful place to live is only possible by refurbishing the current civilization with Islam, which is based on justice, love, and virtue. Bediüzzaman gives the good news that such 
a civilization will develop from the development of current civilization. He also give the glad tidings that the 'real' civilization equipped with general peace and tranquility will rule in the future, and asks people to abandon pessimism and embrace hope:

"Through civilization's iniquities and crimes prevailing over its benefits and its evils being preferred to its virtues, mankind has suffered two calamitous blows in the form of two world wars, and overturning that sinful civilization have been so utterly disgusted that they have smeared the face of the earth with blood. Insha'llah [God willing], through the strength of Islam in the future, the virtues of civilization will predominate, the face of the earth cleansed of filth, and universal peace be secured."

"Just as every winter is followed by spring and every night by morning, mankind, also, shall have a morning and a spring, insha'llah. You may expect from Divine Mercy to see real civilization within universal peace brought about through the sun of the truth of Islam." 54

\section{Closure}

When the topic is terror and weapons of mass destruction, somehow Muslims come to mind first. This casts doubts on Islam, which is a religion of peace founded on love and a religion that equates the murder of one innocent to the murdering of the entire humanity, and on its over a billion followers. The involvement of some people and states in terrorist acts with their Islamic identity and their struggle to develop or possess weapons of mass destruction also feed into these misconceptions. It should be declared from the highest positions of the Islamic world to the entire world with the loudest voice that:

"We as Muslims condemn the use of terror and weapons of mass destruction under all conditions; we view the murder of an innocent as the greatest cruelty and as a crime committed against humanity; and we consider those who attempt to use terror and weapons of mass destruction as the lowest and the cruelest of all people. We as Muslims are destroying all weapons of mass destruction including nuclear weapons - under our possession, and we are terminating all research, development, and manufacturing activities of all such weapons. We also declare to the whole world that, even when we are bombarded with such weapons, we will never respond in kind."

Such a call will have the effect of an atomic bomb in the minds of millions, it will shatter the thick walls of fear and prejudice built around Islam, and by removing the baseless fear and anxiety that are the only causes that can legitimize the use of weapons of mass destruction, and it will serve as a virtual protective shield. This call will be echoed in the conscience of humanity, and it will contribute to the establishment of lasting peace and harmony in the world.

Acknowledgement: Some English translations are adopted from Şükran Vahide's translation of Risale-i Nur. 


\section{Endnotes}

1 Nursi, Mektubat, 2000, İstanbul, Envar Neşriyat, p. 265.

2 Ibid., p. 471.

3 Nursi, Kastamonu Lahikası, 2000, İstanbul, Envar Neşriyat, p. 123.

4 Nursi, Münazarat, 2000, İstanbul, Envar Neşriyat, p. 31.

5 Nursi, Sözler, 2000, İstanbul, Envar Neşriyat, p. 152.

6 Nursi, İşarat-ül Îcaz, 1998, İstanbul, Yeni Asya Neşriyat, p. 95.

7 Nursi, Muhakemat, 2000, İstanbul, Envar Neşriyat, p. 35.

8 Nursi, Hutbe-i Şâmiye, 2000, İstanbul, Envar Neşriyat, p. 38.

9 Nursi, Münazarat, 2000, İstanbul, Envar Neşriyat, p. 29.

10 Nursi, Şualar, 2000, İstanbul, Envar Neşriyat, p. 593.

11 Nursi, Lem 'alar, 2000, İstanbul, Envar Neşriyat, p. 70.

12 Nursi, Muhakemat, 2000, İstanbul, Envar Neşriyat, p. 151.

13 Nursi, Münazarat, 1998, İstanbul, Yeni Asya Neşriyat, p. 33.

14 Ibid., p. 68.

15 Ibid., p. 68.

16 Nursi, Muhakemat, 2000, İstanbul, Envar Neşriyat, p. 152.

17 Nursi, Sünuhat, 2000, İstanbul, Envar Neşriyat, p. 11.

18 Nursi, Muhakemat, 2000, İstanbul, Envar Neşriyat, p. 10.

19 Nursi, Emirdağ Lâhikası 2, 2000, İstanbul, Envar Neşriyat, p. 186.

20 Nursi, Hutbe-i Şâmiye, 2000, İstanbul, Envar Neşriyat, p. 54.

21 Nursi, Münazarat, 2000, İstanbul, Envar Neşriyat, p. 66.

22 Nursi, Hutbe-i Şâmiye, 2000, İstanbul, Envar Neşriyat, p. 45.

23 Nursi, Münazarat, 2000, İstanbul, Envar Neşriyat, p. 32.

24 Nursi, Muhakemat, 2000, İstanbul, Envar Neşriyat, p. 56.

25 Ibid., p. 51.

26 Nursi, Münazarat, 2000, İstanbul, Envar Neşriyat, p. 80.

27 Nursi, Sünuhat, 2000, İstanbul, Envar Neşriyat, p. 48.

28 Nursi, Hutbe-i Şâmiye, 2000, İstanbul, Envar Neşriyat, p. 35.

29 Ibid., p. 90.

30 Ibid., p. 51.

31 Nursi, Muhakemat, 2000, İstanbul, Envar Neşriyat, p. 25.

32 Nursi, Hutbe-i Şâmiye, 2000, İstanbul, Envar Neşriyat, p. 60.

33 Nursi, Sünuhat, 2000, İstanbul, Envar Neşriyat, p. 33. 
34 Nursi, Mesnevî-i Nuriye, 2000, İstanbul, Envar Neşriyat, p. 125.

35 Nursi, Mektubat, 2000, İstanbul, Envar Neşriyat, p. 268.

36 Nursi, Kastamonu Lâhikası, 2000, İstanbul, Envar Neşriyat, p. 123.

37 Nursi, Şualar, 2000, İstanbul, Envar Neşriyat, p. 203.

38 Nursi, Emirdă̆ Lâhikası 2, 2000, İstanbul, Envar Neşriyat, p. 246.

39 Nursi, Mesnevî-i Nuriye, 2000, İstanbul, Envar Neşriyat, p. 69.

40 Nursi, Şualar, 2000, İstanbul, Envar Neşriyat, p. 349.

41 Nursi, Hutbe-i Şâmiye, 2000, İstanbul, Envar Neşriyat, p. 76.

42 Nursi, Sünuhat, 2000, İstanbul, Envar Neşriyat, p. 11.

43 Ibid., p. 23.

44 Ibid., p. 24.

45 Ibid., p. 25.

46 Nursi, Münazarat, 2000, İstanbul, Envar Neşriyat, p. 63.

47 Ibid., p. 15.

48 Nursi, Muhakemat, 2000, İstanbul, Envar Neşriyat, p. 25.

49 Nursi, Münazarat, 2000, İstanbul, Envar Neşriyat, p. 17.

50 Nursi, İşarat-ül Îcaz, 2000, İstanbul, Envar Neşriyat, p. 104.

51 Nursi, Mektubat, 2000, İstanbul, Envar Neşriyat, p. 325.

52 Nursi, Işsarat-ül Îcaz, 2000, İstanbul, Envar Neşriyat, p. 45.

53 Nursi, Mektubat, 2000, İstanbul, Envar Neşriyat, p. 274.

54 Ibid., p. 38. 